\title{
A semi-empirical manganese-in-garnet single crystal thermometer
}

\author{
Steven Creighton \\ Department of Earth and Atmospheric Sciences, University of Alberta, Edmonton, Canada
}

An accurate understanding of the thermal conditions and the thickness of the subcratonic lithospheric mantle is essential for predicting the diamond potential of an area of interest. Mineral exchange thermobarometry of peridotite xenoliths gives the most accurate information regarding the local geothermal gradient and the thickness of the diamond window. During the early stages of diamond exploration programs mantle xenoliths are, however, not routinely identified but mantle derived xenocrystic garnet is common in heavy mineral concentrates. The composition of these garnet xenocrysts can be employed to determine both host rock paragenesis (harzburgitic/lherzolitic or eclogitic sources) and, for peridotitic sources, equilibration temperatures. The commonly applied geothermometer of Griffin et al. (1998) uses the $\mathrm{Ni}$ concentration of peridotitic garnets in equilibrium with olivine with an assumed constant composition. Because the $\mathrm{Ni}$ concentration in peridotitic garnets is typically below the detection limit of electron microprobes (EPMA), LA-ICPMS is commonly used for accurate measurements. The high cost of LA-ICPMS, however, strongly limits the numbers of grains analyzed to indentify high priority targets during diamond exploration. To overcome this impediment, Smith et al. (1991) and Grütter et al. (1999) proposed empirical calibrations based on the concentration of the minor element (within the range of EPMA analyses) manganese in garnet in equilibrium with olivine. Here I present a re-calibration of the Mn-in garnet thermometer based on thermodynamic data and established relative to the garnet-olivine exchange thermometer of O'Neill and Wood (1979).

The temperature dependent exchange of Mn between olivine and garnet can be expressed by the following reaction:

$$
\underset{\text { tephroite }}{3 \mathrm{Mn}_{3} \mathrm{SiO}_{4}}+\underset{\mathrm{Mg}_{2} \mathrm{Al}_{3} \mathrm{Si}_{3} \mathrm{O}_{12}}{2 \text { pyrope }} \underset{\text { forsterite }}{3 \mathrm{Mg}_{2} \mathrm{SiO}_{4}}+\underset{2 \mathrm{Mn}_{2} \mathrm{Al}_{3} \mathrm{Si}_{3} \mathrm{O}_{12}}{\text { spessartine }}
$$

for which an equilibrium constant $\mathrm{K}$ can be defined as:

$$
K=\frac{\left(a_{\text {spess }}^{\text {gar }}\right)^{2}\left(a_{\text {for }}^{\text {olv }}\right)^{3}}{\left(a_{\text {pyr }}^{\text {gar }}\right)^{2}\left(a_{\text {teph }}^{\text {olv }}\right)^{3}}
$$

Activities of spessartine and pyrope in garnet were calculated using a reciprocal solid solution model assuming ideal mixing on the dodecahedral and octahedral sites (Wood and Nicholls 1978) using garnet thermochemical data from Ontonello et al. (1996). Forsterite and tephroite activities in olivine were derived assuming a symmetric solution model with site interaction energy values from Wood et al. (1994).

Calculation of the activities is simplified using covariations observed between composition and activity. The activities of all the components relevant to equation (1) can be described by simple relationships between the mole fraction of either $\mathrm{Mg}$ or $\mathrm{Mn}$ and the activity of the corresponding component. The following linear equations were used to calculate the pyrope and spessartine activities in garnet and the tephroite activity in olivine:

$$
\begin{aligned}
& \mathrm{a}_{\mathrm{py}}^{\text {gar }}=\frac{\mathrm{Mg}}{\mathrm{Mg}+\mathrm{Fe}+\mathrm{Ca}+\mathrm{Mn}}-0.374 \\
& \ln \left(\mathrm{a}_{\mathrm{spss}}^{\mathrm{gar}}\right)=460 \times\left(\frac{\mathrm{Mn}}{\mathrm{Mg}+\mathrm{Fe}+\mathrm{Ca}+\mathrm{Mn}}\right)-18.7 \\
& \ln \left(\mathrm{a}_{\text {teph }}^{\text {olv }}\right)=2153 \times\left(\frac{\mathrm{Mn}}{\mathrm{Mg}+\mathrm{Fe}+\mathrm{Mn}}\right)-14.75
\end{aligned}
$$

The forsterite activity in olivine is best fit with the second degree polynomial equation:

$$
\mathrm{a}_{\text {for }}^{\mathrm{olv}}=4.17 \times\left(\frac{\mathrm{Mg}}{\mathrm{Mg}+\mathrm{Fe}+\mathrm{Mn}}\right)^{2}-6.44 \times\left(\frac{\mathrm{Mg}}{\mathrm{Mg}+\mathrm{Fe}+\mathrm{Mn}}\right)+3.27 \text { (6) }
$$

Using the above simplifications, I have formulated a thermometer based on equilibrium (1) using published and unpublished mineral chemical data from 70 garnet peridotite xenoliths primarily from South African kimberlites. Temperatures were estimated using the garnet-olivine Fe-Mg exchange thermometer of O’Neill and Wood (1979 also O'Neill 1980; T ${ }^{\prime}$ 'Neill) calculated iteratively with pressures determined using the orthopyroxene-garnet barometer of Brey and Köhler (1990, $\mathrm{P}_{\mathrm{BKN}}$ ). Multiple linear regression of the xenolith $\mathrm{P}-\mathrm{T}-\mathrm{ln} \mathrm{K}$ data (Figure 1) provides a reasonable fit to the natural data and yields the following thermometer equation:

$$
\mathrm{T}\left({ }^{\circ} \mathrm{C}\right)=970+92 \times \mathrm{P}-62 \times \ln (\mathrm{K})(\mathrm{P} \text { in } \mathrm{GPa})
$$

This formulation reproduces $\mathrm{T}_{\mathrm{O} \text { 'Neill }}$ of the xenoliths to better than $\pm 100^{\circ} \mathrm{C}$ calculated at $\mathrm{P}_{\mathrm{BKN}}$ for a dataset of 
311 garnet-bearing xenoliths from worldwide locations and hence has a precision comparable to $\mathrm{T}_{\mathrm{Ni}}$.

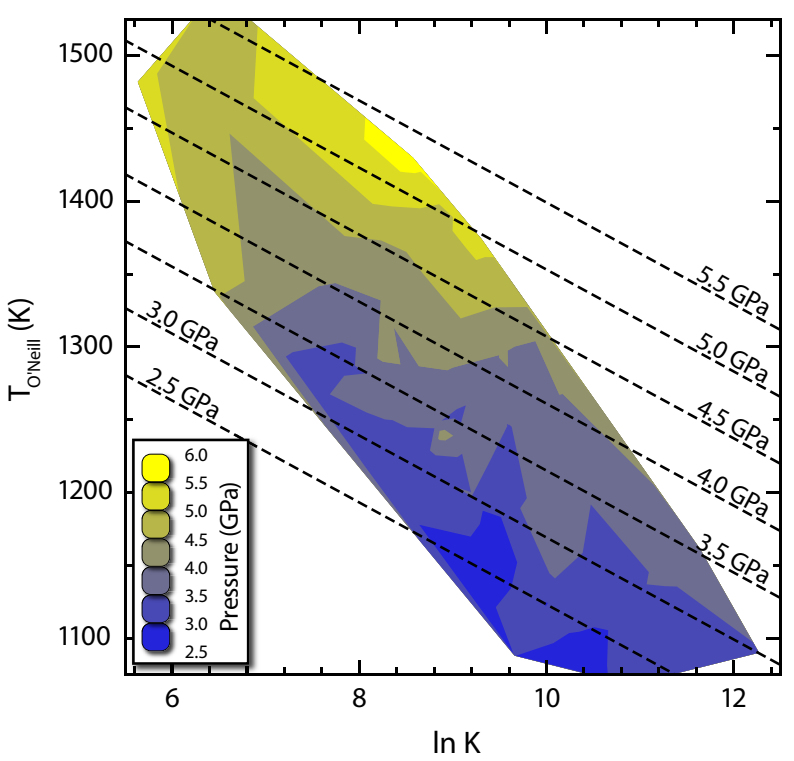

Figure 1: Olivine-garnet Fe-Mg exchange temperature ( $\left.\mathrm{T}_{\mathrm{O} \text { 'Neill }}\right)$ in Kelvin vs. $\ln \mathrm{K}$ of mantle xenoliths from South African kimberlites. The data are contoured in pressure $\left(\mathrm{P}_{\mathrm{BKN}}\right)$ showing the co-dependency of $\mathrm{K}$ on both $\mathrm{P}$ and $\mathrm{T}$.

In order to apply this thermometer to peridotitic garnets for diamond exploration two additional input parameters are required that cannot be directly derived from garnet EPMA analyses. First, a correction for the unknown equilibration pressure of garnet xenocrysts must be used in place of $\mathrm{P}_{\mathrm{BKN}}$ and second, reasonable activities of forsterite and tephroite in mantle-derived olivine must be assumed. The pressure dependency of $\mathrm{K}$ (Figure 1) may be used to derive a pressure correction for the thermometer. Regression of the P-TIn K relationship of the same xenolith database leads to the following pressure correction:

$$
\mathrm{P}^{*}=8.75-0.554 \times \ln (\mathrm{K})
$$

Which may be substituted into equation 7 to give the pressure corrected $\mathrm{T}_{\mathrm{Mn}}$ :

$$
\mathrm{T}_{\mathrm{Mn}}\left({ }^{\circ} \mathrm{C}\right)=1775-86 \times \ln (\mathrm{K})
$$

The pressure corrected $\mathrm{T}_{\mathrm{Mn}}$ reproduces $\mathrm{T}_{\mathrm{O} \text { 'Neill from }}$ $\sim 700$ to $1450^{\circ} \mathrm{C}$ within $\pm 150^{\circ} \mathrm{C}$ for 289 of the 311 xenoliths (93\%) in the database (Figure 2).

The choice of assumed forsterite and tephroite activities in olivine for the Mn-in-garnet thermometer depends on the application. The information most pertinent for diamond exploration is whether a garnet derives from within the diamond stability field. A large proportion of garnets from depleted harzburgitic sources within the diamond stability field would indicate a high priority target. Hence, a thermometer (using temperature as a proxy for depth) should be most accurate in the temperature range where the diamond-graphite transition intersects the local geothermal gradient. The diamond-graphite transition (Kennedy and Kennedy 1976) occurs in cratonic mantle lithosphere within a temperature range from approximately $900^{\circ} \mathrm{C}$ to $1150^{\circ} \mathrm{C}$ assuming that P-T covariation in subcratonic lithospheric mantle may be described by model conductive geotherms from 38 to $44 \mathrm{~mW} / \mathrm{m}^{2}$ surface heat flow (Pollack and Chapman 1977). The average forsterite and log tephroite activities of 120 olivines from xenoliths with temperatures within the specified range are 0.879 and 5.44, respectively. Substituting these values into equation 2, for use as a single crystal thermometer, produces results with slightly larger error than temperatures calculated with known olivine compositions but $86 \%$ are within $\pm 150^{\circ} \mathrm{C}$ of $\mathrm{T}_{\mathrm{O} \text { 'Neill }}$ (Figure 3). Relative to $\mathrm{T}_{\mathrm{O} \text { 'Neill, }}$ my formulation underestimates the temperature of several sheared peridotites that have equilibration temperatures $>1350^{\circ} \mathrm{C}$.

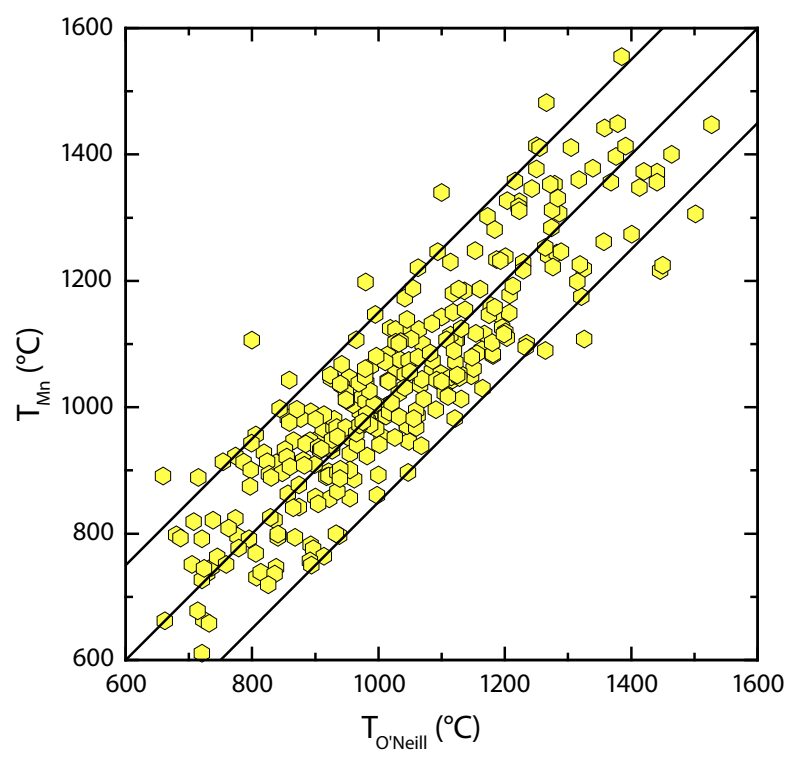

Figure 2: Comparison of $\mathrm{T}_{\mathrm{O}}$ Neill and $\mathrm{T}_{\mathrm{Mn}}$ for xenoliths with known olivine compositions. The $\mathrm{T}_{\mathrm{Mn}}$ for most xenoliths is within $\pm 150^{\circ} \mathrm{C}$ of $\mathrm{T}_{\mathrm{O}^{\prime} \text { Neill }}$.

Comparison with the two previous empirical formulations (Smith et al. 1991; Grütter et al. 1999) indicates improved precision of my re-calibration. The formulation of Smith et al. (1991) when used as a single crystal thermometer (using an average mantle olivine $\mathrm{MnO}$ concentration of 0.104 wt $\%$ ) systematically underestimates $\mathrm{T}_{\mathrm{O}^{\prime} \text { Neill }}$ by $150^{\circ} \mathrm{C}$ below $800^{\circ} \mathrm{C}$ and overestimates at $\mathrm{T}_{\mathrm{O}^{\prime} \text { Neill }}>1100^{\circ} \mathrm{C}$ by $150-$ $300^{\circ} \mathrm{C}$. The garnet-olivine Mn thermometer of Grütter et al. (1999) overestimates temperatures with deviations being most pronounced at temperatures below $\sim 1000^{\circ} \mathrm{C}$, leading to an overestimation of the proportion of samples derived from the diamond stability field. 


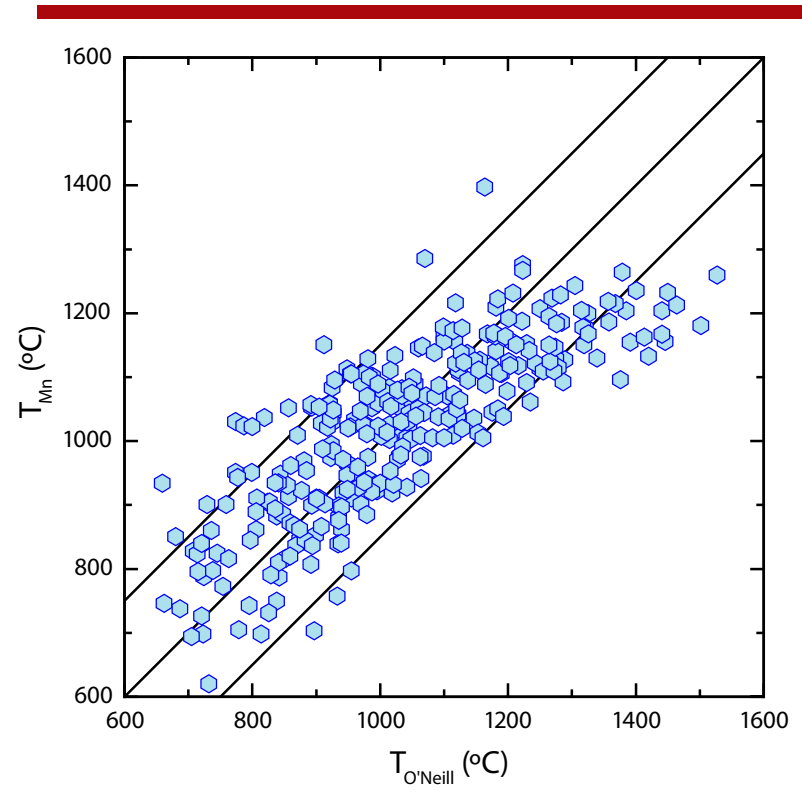

Pollack HN, Chapman DS (1977) On the regional variation of heat flow, geotherms, and lithospheric thickness. Tectonophysics 38:279-296

Smith D, Griffin W, Ryan C, Sie S (1991) Trace-element zonation in garnets from The Thumb: heating and melt infiltration below the Colorado Plateau. Contrib Mineral Petrol 107:60-79

Wood B, Hackler R, Dobson D (1994) Experimental determination of $\mathrm{Mn}-\mathrm{Mg}$ mixing properties in garnet, olivine and oxide. Contrib Mineral Petrol $115: 438-448$

Wood BJ, Nicholls J (1978) The thermodynamic properties of reciprocal solid solutions. Contrib Mineral Petrol 66:389-400

Figure 3: Comparison of $\mathrm{T}_{\mathrm{O}}{ }^{\prime}$ Neill for xenoliths with known olivine compositions and $\mathrm{T}_{\mathrm{Mn}}$ calculated with assumed olivine compositions. The scatter is somewhat larger than Figure 2 but $\mathrm{T}_{\mathrm{Mn}}$ for most xenoliths is still within $\pm 150^{\circ} \mathrm{C}$ of $\mathrm{T}_{\mathrm{O} \text { 'Neill. }}$ The samples with underestimated $\mathrm{T}_{\mathrm{Mn}}$ at $\mathrm{T}_{\mathrm{O} \text { 'Neill }}$ $>1350^{\circ} \mathrm{C}$ are sheared xenoliths mainly from Lesotho.

\section{References}

Brey GP, Köhler T (1990) Geothermobarmetry in four-phase lherzolites II. New thermometers, and practical assessment of existing thermobarometers. J Petrol 31:1353-1378

Griffin WL, Cousens DR, Ryan CG, Sie SH, Suter GF (1998) $\mathrm{Ni}$ in chrome pyrope garnets: a new geothermometer. Contrib Mineral Petrol 103:199202

Grütter H, Apter DB, Kong J (1999) Crust-Mantle Coupling: Evidence from Mantle-Derived Xenocrystic Garnets. In: Gurney JJ, Gurney JL, Pascoe MD, Richardson SH (eds) Proceedings of the VII ${ }^{\text {th }}$ International Kimberlite Conference, vol 1. Red Roof Design, Cape Town, South Africa, pp 307313

Kennedy CS, Kennedy GC (1976) The equilibrium boundary between graphite and diamond. J Geophys Res 81:2467-2470

O'Neill HSC (1980) An experimental study of Fe-Mg partitioning between garnet and olivine and its calibration as a geothermometer: Corrections. Contrib Mineral Petrol 72:337

O'Neill HSC, Wood BJ (1979) An experimental study of FeMg partitioning between garnet and olivine and its calibration as a geothermometer. Contrib Mineral Petrol 70:59-70

Ottonello G, Bokreta M, Sciuto P (1996) Parameterization of energy and interactions in garnets; end-member properties. Am Min 81:429-447 